\title{
Effects of leptin on fracture healing in rat tibia
}

\author{
Sıçan tibiasında kırık iyileşmesinde leptinin etkileri
}

\begin{abstract}
Gökçen Kerimoğlu, M.D., ${ }^{1}$ Esin Yuluğ, M.D., ${ }^{2}$ Servet Kerimoğlu, M.D., ${ }^{3}$ Atilla Çıtlak, M.D. ${ }^{4}$
'Department of Histology and Embryology, Trabzon Kanuni Training and Research Hospital, Trabzon, Turkey

2Department of Histology and Embryology, Medical Faculty of Karadeniz Technical University, Trabzon, Turkey

${ }^{3}$ Department of Orthopedics and Traumatology, Medical Faculty of Karadeniz Technical University, Trabzon, Turkey

${ }^{4}$ Department of Orthopedics and Traumatology, Medical Faculty of Giresun University, Giresun, Turkey
\end{abstract}

\begin{abstract}
Objectives: In this study, we aimed to evaluate possible effects of leptin on fracture healing.

Materials and methods: Between November 2009 and May 2010, 54 male Sprague Dawley rats with a mean age of 16 weeks and a mean body weight of $323 \mathrm{~g}$ (range; 295-352 g) were included and randomly divided into three equal groups. Standardized tibial fractures were created to all rats. Group 1 was treated with $0.5 \mathrm{~mL}$ physiological saline, group 2 was treated with $0.1 \mu \mathrm{g} / \mathrm{kg}$ leptin within $0.5 \mathrm{~mL}$ physiological saline, and group 3 was treated $0.3 \mu \mathrm{g} / \mathrm{kg}$ leptin within $0.5 \mathrm{~mL}$ physiological saline for 14 days intraperitoneally. Each group was divided into three subgroups including six rats for the evaluation at second, third and fifth weeks.
\end{abstract}

Results: Radiological evaluation showed that fracture healing of group 3 was better than group $1(p=0.014)$ only at fifth week. Histological evaluation revealed fracture healing of group 3 was better than group 1 at third week $(\mathrm{p}=0.011)$. At fifth week, both group 2 and group 3 had better fracture healing than group $1(\mathrm{p}=0.006, \mathrm{p}=0.002$, respectively). There was no statistically significant difference in fracture healing between group 2 and 3 at fifth week $(p=0.176)$.

Conclusion: Leptin has a positive dose-dependent effect on rat tibial fracture healing.

Key words: Fracture healing; leptin; rat; tibial fracture.

The relationship between body fat mass and bone metabolism has recently attracted the attention of researchers. Lately, the important functional role that the adipokine leptin provides between bone and fat tissue has gained popularity, but many points in this role have not been fully clarified. ${ }^{[1]}$
Amaç: Bu çalışmada leptinin kırık iyileşmesi üzerine olabilecek muhtemel etkileri değerlendirildi.

Gereç ve yöntemler: Kasım 2009 - Mayıs 2010 tarihleri arasında ortalama yaşları 16 hafta ve ortalama vücut ağırlıkları 323 g (dağılım; 295-352 g) olan 54 Sprague Dawley erkek sıçan çalışmaya alındı ve rastgele eşit üç gruba ayrıldı. Bütün sıçanlarda standart tibia kırığı oluşturuldu. Grup 1'e $0.5 \mathrm{ml}$ serum fizyolojik, grup 2'ye $0.1 \mu \mathrm{g} / \mathrm{kg}$ leptin $0.5 \mathrm{ml}$ serum fizyolojik, ve grup 3'e ise $0.3 \mu \mathrm{g} / \mathrm{kg}$ leptin $0.5 \mathrm{ml}$ serum fizyolojik içinde olacak şekilde 14 gün boyunca intraperitoneal olarak uygulandı. Her bir grup da kendi içerisinde ikinci, üçüncü ve beşinci haftalarda değerlendirilmek için altışar siçandan oluşan üçer alt gruba ayrıldı.

Bulgular: Radyolojik değerlendirme sonucunda yalnızca beşinci haftada grup 3'ün kırık iyileşmesi, grup 1'e kıyasla, daha iyiydi $(\mathrm{p}=0.014)$. Histolojik değerlendirmede üçüncü haftada grup 3'ün kırık iyileşmesi, grup l'e kıyasla, daha iyiydi $(\mathrm{p}=0.011)$. Beşinci haftada ise hem grup 2, hem de grup 3 , grup 1'e kıyasla, daha iyi kırık iyileşmesine sahipti (sırasıyla, $\mathrm{p}=0.006, \mathrm{p}=0.002$ ). Grup 2 ve 3 arasında beşinci haftada kırık iyileşmesi açısından anlamlı bir fark yoktu $(\mathrm{p}=0.176)$.

Sonuç: Leptin sıçan tibia kırık iyileşmesi üzerine doza bağımlı olarak olumlu etkiye sahiptir.

Anahtar sözcükler: Kırık iyileşmesi; leptin; sıçan; tibia kırı̆̆ı.

Leptin is a peptide hormone which is secreted especially by white adipose tissue and encoded by obese gene. Leptin arranges the size of fat tissue by affecting food intake and energy consumption..$^{[2,3]}$ Many studies have been conducted to investigate the effects of leptin on bone mass, because bone

- Received: August 15, 2012 Accepted: March 16, 2013

- Correspondence: Servet Kerimoğlu, M.D. Karadeniz Teknik Üniversitesi Tıp Fakültesi, Ortopedi ve Travmatoloji Anabilim Dalı, 61080 Trabzon, Turkey. Tel: +90 505 - 5843274 Fax: +90 462 - 3250518 e-mail: serkerim70@yahoo.com 
and fat tissue cells are differentiated from the same mesenchymal stem cells. ${ }^{[1,4-7]}$ Leptin increases differentiation of bone marrow stromal cells to osteoblasts and decreases differentiation to adipocytes. ${ }^{[4]}$ In addition, leptin has an important role in arrangement of chondrocyte differentiation on growth plate and cartilage matrix maturation by endocrine and paracrine mechanisms. ${ }^{[5]}$ Also leptin effects osteoblast differentiation and proliferation, and coordinates skeletal development. ${ }^{[6]}$ Leptin hormone's effect on bone formation is not only as a systemic hormone, but also as a local factor by organizing angiogenesis in endochondral ossification. ${ }^{[7]}$ Systemic application of leptin has a direct effect on osteoblasts and osteoclasts, and reduces bone fragility. ${ }^{[1]}$

Studies on the effects of leptin on chondrocyte, osteoblast differentiation and angiogenesis especially led us to investigate leptin's possible positive effects on fracture healing.

\section{MATERIALS AND METHODS}

This experimental study was conducted in the experimental research laboratory and histology laboratory between November 2009 - May 2010 following approval by the ethical committee of the university (10.27.2009/1). Fifty-four male Sprague Dawley rats with a mean age of 16 weeks and a mean body weight of $323 \mathrm{~g}$ (range, 295-352 g) were randomly and equally divided into three groups. Group 1 was treated with $0.5 \mathrm{~mL}$ physiological saline intraperitoneally and used as operative control group. Group 2 was treated with $0.1 \mu \mathrm{g} / \mathrm{kg}$ leptin (Leptin Rat, Recombinant, Bio Vendor, Czech. Republic) in $0.5 \mathrm{~mL}$ physiological saline intraperitoneally. Group 3 was treated with $0.3 \mu \mathrm{g} / \mathrm{kg}$ leptin in $0.5 \mathrm{~mL}$ physiological saline intraperitoneally. Treatments were started on the day of surgery and repeated at the same time daily for 14 days. All three groups were divided into three subgroups ( $\mathrm{n}=6$ rats) for evaluation at second, third and fifth weeks after the operation.

\section{Surgical technique}

After the adaptation period of seven days, the rats were fasted four hours before surgery. Five $\mathrm{mg} / \mathrm{kg}$ xylazine hydrochloride (Rompun; Bayer Healthcare, Leverkusen, Germany) and $50 \mathrm{mg} / \mathrm{kg}$ ketamine hydrochloride (Ketalar; Pfizer, İstanbul, Turkey) were injected intraperitoneally as anesthetic. The rats were placed in the supine position and the skin overlying the right tibia was swabbed before and after surgery with a 10\% povidone iodine solution (Batticon; Adeka, Samsun, Turkey).
A Kirschner wire (1.0 mm diameter) was threaded into the medullary cavity of the right tibia through the skin and patellar ligament over the knee and was advanced down to the distal end of the tibia. The tibia was exposed by a longitudinal median skin incision directly over the bone. Using a drill, three holes were made at right angles in the midshaft of the tibia. Light manual bending gently broke the tibia while the Kirschner wire was held in place in the medullary canal. ${ }^{[8]}$ The skin incision was closed with 3.0 Vicryl rapid. The same surgeon performed all surgeries. The animals were permitted full weight bearing and unrestricted movement after anesthesia. No antibiotics were administered to rats preoperatively and postoperatively.

The animals were anesthetized and euthanized by cervical dislocation. The right legs of the rats were amputated above the knee joint. The tibias were $X$-rayed and stripped from the soft tissues and stored in $10 \%$ formaldehyde for histological evaluation.

\section{Histological evaluation}

The specimens were prepared and fixed in $10 \%$ buffered formaldehyde for 48 hours. ${ }^{[9]}$ Then they were decalcified in $10 \%$ formic acid solution at room temperature for 20 days. Subsequently, the samples were washed with water for four hours and dehydrated in alcohol, cleared in xylol, embedded in paraffin. ${ }^{[10]}$ Using a microtome (Leica RM2255, Tokyo, Japan) 5 -mcm-thick longitudinal serial sections were taken from the specimens and stained with hematoxylin and eosin. All sections were examined under a light microscope (Olympus BX51, Shibuya$\mathrm{ku}$, Tokyo, Japan) with a digital camera (Olympus DP71, Olympus Optical Co, Ltd, Tokyo, Japan) and the images were captured. The criteria described by Huo et al. ${ }^{[11]}$ were used for histological evaluation of the specimens.

\section{Radiological evaluation}

The bone formation part of the Lane-Sandhu scoring system was used for radiological evaluation of the fracture healing. ${ }^{[12]}$ The standard lateral radiographs that were taken after euthanasia were evaluated by a blinded observer.

\section{Statistical evaluation}

The comparison among groups was performed using Kruskal-Wallis analysis of variance (MannWhitney U-test as post-hoc test). The data which were obtained from measurements indicated as mean (min-max). Significance ratio was $\mathrm{p}<0.05$; in multiple comparisons (post-hoc) significance ratio was $\mathrm{p}<0.05 /$ number of comparisons. 
TABLE I

Radiological and histological results of the groups

\begin{tabular}{|c|c|c|c|c|c|c|c|c|c|c|c|c|}
\hline & \multicolumn{4}{|c|}{ Second week } & \multicolumn{4}{|c|}{ Third week } & \multicolumn{4}{|c|}{ Fifth week } \\
\hline & \multicolumn{2}{|c|}{$\begin{array}{l}\text { Radiological } \\
\text { results }\end{array}$} & \multicolumn{2}{|c|}{$\begin{array}{l}\text { Histological } \\
\text { results }\end{array}$} & \multicolumn{2}{|c|}{$\begin{array}{l}\text { Radiological } \\
\text { results }\end{array}$} & \multicolumn{2}{|c|}{$\begin{array}{l}\text { Histological } \\
\text { results }\end{array}$} & \multicolumn{2}{|c|}{$\begin{array}{l}\text { Radiological } \\
\text { results }\end{array}$} & \multicolumn{2}{|c|}{$\begin{array}{l}\text { Histological } \\
\text { results }\end{array}$} \\
\hline & Median & Min.-max. & Median & Min.-max. & Median & Min.-max. & Median & Min.-max. & Median & Min.-max. & Median & Min.-max. \\
\hline Group 1 & 0.5 & $0-1$ & 4 & $3-5$ & 2 & $1-2$ & 5 & $5-6$ & 2.5 & $2-3$ & 6 & $5-6$ \\
\hline Group 2 & 1 & $0-1$ & 4.5 & $3-5$ & 2 & $2-3$ & 6 & $5-6$ & 3.5 & $3-4$ & 7 & $6-7$ \\
\hline Group 3 & 1 & $1-2$ & 5 & $4-6$ & 2.5 & $2-3$ & 6.5 & $6-7$ & 4 & $3-4$ & 7 & $7-8$ \\
\hline
\end{tabular}

Min.: Minimum; Max.: Maximum.

\section{RESULTS}

The radiological and histological results of the groups are summarized in Table I.

\section{Clinical results}

There was no complication related to anesthesia and intraperitoneal interventions. Postoperative limping was seen for five-six days, and then the rats used their extremities in normal fashion. There was no wound infection and no complications related to surgery. No rat died throughout the experiment.

\section{Radiological results}

In all rats different degrees of union was seen in radiographs (Figure 1a-c). There was no statistically significant difference between the groups at the second and third weeks $(p=0.052, p=0.052$, respectively). At the fifth week, there was a statistically significant difference between the groups $(p=0.014)$. Fracture healing in group 3 was better than group $1(\mathrm{p}=0.011)$, but there was no difference between groups 2 and 3 according to fracture healing ( $\mathrm{p}=0.575)$. In all groups, there was statistically significant difference between second, third and fifth week subgroups $(p=0.002$, $\mathrm{p}=0.001, \mathrm{p}=0.001$, respectively).

\section{Histological results}

There was no statistically significant difference between groups at the second week $(p=0.102)$. At the third and fifth weeks, there was a statistically significant difference between groups $(p=0.012$, $\mathrm{p}=0.001$, respectively).

At the third week, fracture healing in group 3 was better than in group $1(\mathrm{p}=0.011)$. In group 1 , equal amounts of cartilage and woven bone were observed at the third week (Figure 2a). In group 2, equal amounts of cartilage and woven bone, and some bone marrow within woven bone were observed in the fracture line (Figure 2b). In group 3, predominantly woven bone with some cartilage was observed at the third week (Figure 2c).
At the fifth week, there was a statistically significant difference between group 1 and 2, and between group 1 and 3 ( $\mathrm{p}=0.006, \mathrm{p}=0.002$, respectively). There was no statistically significant difference between group 2 and $3(\mathrm{p}=0.176)$. In group 1 predominantly cartilage with some woven bone was observed. In group 2 predominantly woven bone with some cartilage islands was observed in the fracture line. In group 3 predominantly woven bone spicules with little cartilage islands was observed. In all groups, there was a statistically significant difference between the second, third and fifth week subgroups $(p=0.002$, $\mathrm{p}=0.001, \mathrm{p}=0.002$, respectively).

\section{DISCUSSION}

Bone injuries increase in frequency and severity associated with the growing world population and developing technology, and remains a current problem in medicine for physicians and patients. ${ }^{[13]}$ Fracture healing studies in the literature have been increasing in frequency ${ }^{[14-17]}$ Fracture healing including interaction between cells, growth factors, and extracellular matrix is a wound healing process which summarizes skeletal growth and development. Inflammatory cells, vascular cells, osteochondral progenitor cells and osteoclasts play an important role at the cellular level of the repair process. Proinflammatory cytokines, growth factors, proosteogenic factors and angiogenic factors play a role at the molecular level of the bone repair process. ${ }^{[13,18,19]}$

Studies to explain the relationship between body fat mass and bone metabolism are also increasing continuously. Peripheral body fat appears to influence bone mass via secretion of systemic and endocrine factors. The cytokine-like hormone leptin, which is secreted by fat cells, is an important candidate for functional connection between bone and fat tissue. ${ }^{[20-22]}$

Experimental studies showed that elevation of serum leptin levels starts immediately after trauma 
such as a femoral fracture, spinal cord injury or traumatic brain injury by activation of endogenous leptin secretion. These higher leptin levels are associated with increased callus formation in the fracture site ${ }^{[23,24]}$ furthermore elevated serum leptin may act peripherally to induce myeloid precursor cell differentiation, osteoblast proliferation, and accelerate the mineralization of bone at the fracture site. ${ }^{[4,21,23,24]}$ We think that because daily application of exogenous leptin might provide consistently higher concentrations of serum leptin levels, better fracture healing was observed in the groups given exogenous leptin in our study (Figure 1a-c and 2a-c).

In the study of Wang et al., ${ }^{[23]}$ the group which got the highest serum leptin levels for a longer time
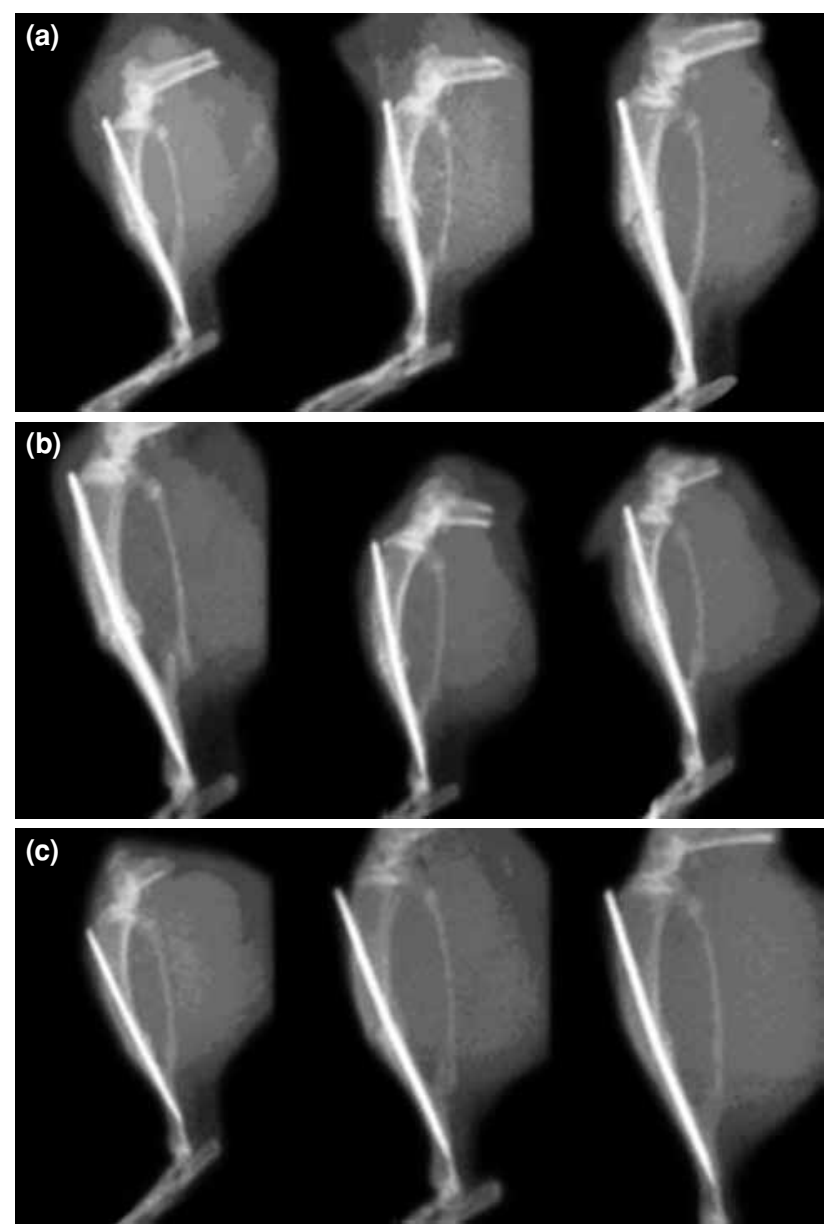

Figure 1. (a) Second week radiological images of groups: A full fracture line is seen in all groups. According to our evaluation method no significant difference was appreciated between groups. (b) Third week radiological images of groups: The fracture lines begin to disappear in group 3. According to our evaluation method no significant difference was appreciated between groups. (c) Fifth week radiological images of groups: There was a statistically significant difference between group 1 and 3. had the most increased callus formation. Similarly, in our study, fracture healing was better in the group in which more exogenous leptin was administered. Some studies in the literature stated that leptin inhibits differentiation of bone marrow stromal cells to
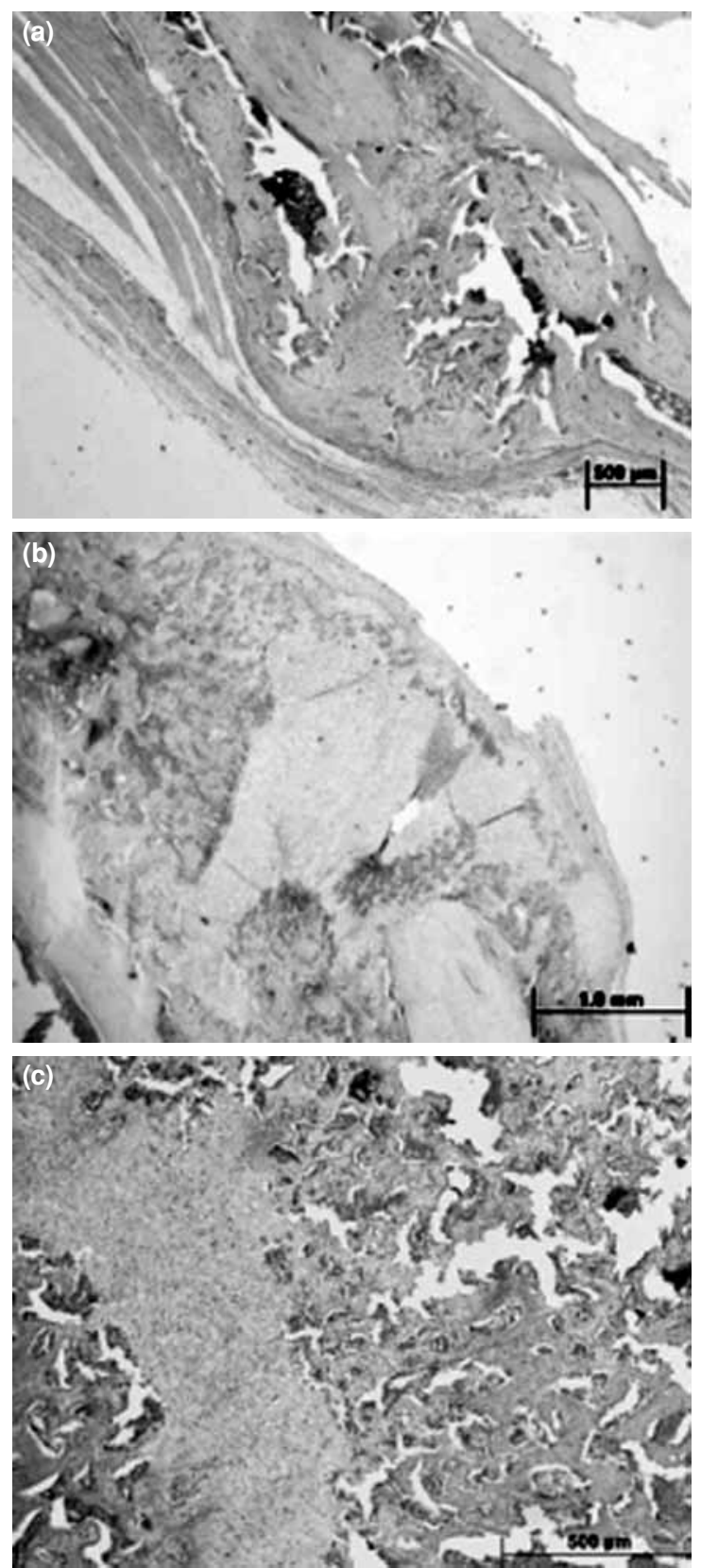

Figure 2. (a) Third week histological section of group 1: Equal amounts of cartilage and woven bone were observed in the fracture line ( $\mathrm{H}-\mathrm{E} \times 40)$. (b) Third week histological section of group 2: Equal amounts of cartilage and woven bone, and some bone marrow within woven bone was observed in the fracture line (H-E x 100). (c) Third week histological section of group 3: Predominantly woven bone with some cartilage islands was observed in the fracture line (H-E x 100). 
adipogenesis, and stimulates differentiation of bone marrow stromal cells to osteoblasts. ${ }^{[4,6]}$ Leptin can be effective at the cellular level in fracture healing. Also, leptin binds directly to the receptors on the osteoblasts and increases osteoblast growth and bone mineralization..$^{[2]]}$ To increase not only osteoblast but also chondrocyte differentiation contributes to fracture healing.

Angiogenesis is provocated in fracture healing for provision of nutrients, cells and biological mediators and for disposal of waste products. Angiogenesis has an important role not only in intramembranous but also in endochondral ossification. ${ }^{[25,26]}$ These are natural stages of fracture healing. Bouloumié et al. ${ }^{[27]}$ emphasized leptin is a powerful modulator of angiogenesis. Leptin effects endothelial cell migration and activation in vitro, and angiogenesis in vivo. As a result, in our study treatment with leptin increases fracture healing, so we think that leptin's effect on angiogenesis may have played a role in this increase.

The mechanism of positive effect of leptin on fracture healing was not clearly identified, but we think that its effect on regulation of angiogenesis in endochondral ossification, and positive effect on osteoblast and chondrocyte differentiation and growth, and effect on bone turnover can produce this result.

In our study we observed a dose dependent positive effect of leptin on fracture healing when we evaluated radiological and especially histological results. In all groups both radiological and histological data obtained continuously without interruption, indicated the suitability of the applied method. When we compared histological results with similar studies in the literature, the control group was found to be compatible with the literature. ${ }^{[16,17]}$ The weaknesses of the study include our not determining leptin concentrations in serum, and not performing biomechanical testing of the callus.

In conclusion, intraperitoneal exogenous leptin application has a positive dose dependent effect on rat tibial fracture healing.

\section{Declaration of conflicting interests}

The authors declared no conflicts of interest with respect to the authorship and/or publication of this article.

\section{Funding}

The authors received no financial support for the research and/or authorship of this article.

\section{REFERENCES}

1. Cornish J, Callon KE, Bava U, Lin C, Naot D, Hill BL, et al. Leptin directly regulates bone cell function in vitro and reduces bone fragility in vivo. J Endocrinol 2002;175:405-15.

2. Voet D, Voet JG, Pratt CW. Mammalian fuel metabolism: Integration and regulation. In: Voet D, Voet JG, Pratt CW, editors. Fundamentals of biochemistry life at the molecular level. USA: John Wiley \& Sons; 2006. p. 743-86.

3. Zhang Y, Proenca R, Maffei M, Barone M, Leopold L, Friedman JM. Positional cloning of the mouse obese gene and its human homologue. Nature 1994;372:425-32.

4. Thomas T, Gori F, Khosla S, Jensen MD, Burguera B, Riggs BL. Leptin acts on human marrow stromal cells to enhance differentiation to osteoblasts and to inhibit differentiation to adipocytes. Endocrinology 1999;140:1630-8.

5. Kishida Y, Hirao M, Tamai N, Nampei A, Fujimoto T, Nakase $\mathrm{T}$, et al. Leptin regulates chondrocyte differentiation and matrix maturation during endochondral ossification. Bone 2005;37:607-21.

6. Bertoni L, Ferretti M, Cavani F, Zavatti M, Resca E, Benelli A, et al. Leptin increases growth of primary ossification centers in fetal mice. J Anat 2009 ;215:577-83. doi: 10.1111/j.1469-7580.2009.01134.x.

7. Kume K, Satomura K, Nishisho S, Kitaoka E, Yamanouchi $\mathrm{K}$, Tobiume $\mathrm{S}$, et al. Potential role of leptin in endochondral ossification. J Histochem Cytochem 2002;50:159-69.

8. Luger EJ, Rochkind S, Wollman Y, Kogan G, Dekel S. Effect of low-power laser irradiation on the mechanical properties of bone fracture healing in rats. Lasers Surg Med 1998;22:97-102.

9. Bancroft JD, Cook HC. Specialized biopsies. In: Bancroft JD, Cook HC, editors. Manual of histological techniques and their diagnostic application. London: Churchill Livingstone; 1994. p. 373-413.

10. Demir R. Temel histolojik teknikler. In: Demir R, editör. Histolojik boyama teknikleri. Ankara: Palme Yayıncılık; 2001. p. 1-49.

11. Huo MH, Troiano NW, Pelker RR, Gundberg CM, Friedlaender GE. The influence of ibuprofen on fracture repair: biomechanical, biochemical, histologic, and histomorphometric parameters in rats. J Orthop Res 1991;9:383-90.

12. Lane JM, Sandhu HS. Current approaches to experimental bone grafting. Orthop Clin North Am 1987;18:213-25.

13. Buckwalter JA, Einhorn TA, Marsh JL. Bone and joint healing. In: Bucholz RW, Heckman JD, Court-Brown C, editors. Rockwood and Green's fractures in adults. 6th ed. Philadelphia: Lippincott Williams \& Wilkins; 2006. p. 297-330.

14. Akkaya S, Nazalı M, Kılıç A, Bir F. Cefazolin-sodium has no adverse effect on fracture healing in an experimental rabbit model. Eklem Hastalik Cerrahisi 2012;23:44-8.

15. Aydin K, Sahin V, Gürsu S, Mercan AS, Demir B, Yildirim T. Effect of pentoxifylline on fracture healing: an experimental study. Eklem Hastalik Cerrahisi 2011;22:160-5.

16. Cebesoy O, Tutar E, Kose KC, Baltaci Y, Bagci C. Effect of strontium ranelate on fracture healing in rat tibia. Joint Bone Spine 2007;74:590-3.

17. Kerimoğlu S, Livaoğlu M, Sönmez B, Yuluğ E, Aynaci O, Topbas M, et al. Effects of human amniotic fluid on fracture healing in rat tibia. J Surg Res 2009;152:281-7. doi: 10.1016/j. jss.2008.02.028.

18. Schindeler A, McDonald MM, Bokko P, Little DG. Bone 
remodeling during fracture repair: The cellular picture. Semin Cell Dev Biol 2008;19:459-66. doi: 10.1016/j. semcdb.2008.07.004.

19. Barnes GL, Kostenuik PJ, Gerstenfeld LC, Einhorn TA. Growth factor regulation of fracture repair. J Bone Miner Res 1999;14:1805-15.

20. Fu L, Patel MS, Bradley A, Wagner EF, Karsenty G. The molecular clock mediates leptin-regulated bone formation. Cell 2005;122:803-15.

21. Reseland JE, Syversen U, Bakke I, Qvigstad G, Eide LG, Hjertner $\mathrm{O}$, et al. Leptin is expressed in and secreted from primary cultures of human osteoblasts and promotes bone mineralization. J Bone Miner Res 2001;16:1426-33.

22. Hamrick MW, Ferrari SL. Leptin and the sympathetic connection of fat to bone. Osteoporos Int 2008;19:905-12.

23. Wang L, Tang X, Zhang H, Yuan J, Ding H, Wei Y. Elevated leptin expression in rat model of traumatic spinal cord injury and femoral fracture. J Spinal Cord Med 2011;34:5019. doi: 10.1179/2045772311Y.0000000034.

24. Wang L, Yuan JS, Zhang HX, Ding $H$, Tang XG, Wei YZ. Effect of leptin on bone metabolism in rat model of traumatic brain injury and femoral fracture. Chin J Traumatol 2011;14:7-13.

25. Lienau J, Schmidt-Bleek K, Peters A, Haschke F, Duda GN, Perka C, et al. Differential regulation of blood vessel formation between standard and delayed bone healing. J Orthop Res 2009;27:1133-40. doi: 10.1002/jor.20870.

26. Glowacki J. Angiogenesis in fracture repair. Clin Orthop Relat Res 1998;S82-9.

27. Bouloumié A, Drexler HC, Lafontan M, Busse R. Leptin, the product of $\mathrm{Ob}$ gene, promotes angiogenesis. Circ Res 1998;83:1059-66. 